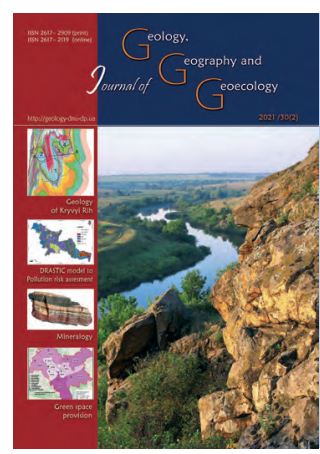

Makarenko P. O.

\section{Journal of Geology. Geography and Geoecology}

Journal home page: geology-dnu.dp.ua
ISSN 2617-2909 (print)

ISSN 2617-2119 (online)

Journ.Geol.Geograph. Geology, 30(2), 326-333.

doi: $10.15421 / 112129$

\title{
Analysis of the monopolization level of raw material exports of Ukraine
}

\author{
Petro O. Makarenko \\ Institute of Geography of NAS of Ukraine, Kyiv, Ukraine, m_peter@ukr.net
}

Received: 23.09.2020

Received in revised form: 15.12 .2020

Accepted: 08.02.2021 \begin{abstract}
economy and a decrease in its efficiency. The cu,
\end{abstract} The current trend of increasing exports of raw materials and the monopolization of major export industries makes Ukraine's economy even more dependent on the activities of several monopolists. The aim of this work was to analyze the level of monopolization of the main Ukrainian export categories - agricultural and iron industry production. Methods of this study were based on analysis of literature of the national authors, systematization and generalization of data of the State Statistics Service of Ukraine, the Antimonopoly Committee of Ukraine and other open sources. The study found that the agricultural sector of the Ukrainian economy has a dual structure - corporate (agricultural holdings) and individual farms (family farms and households), which are characterized by different directions of development. The analysis of the regional presence of agricultural holdings showed that the largest landowners cultivate land plots in almost all regions of Ukraine. At present time in the agro-industrial sector of Ukraine corporate landowners control $18.4 \%$ of arable land, exist in the form of vertically integrated holdings specializing in the cultivation of export-oriented crops. The study found that specific location of minerals explains the geographical location of iron industry enterprises in Dnipro, Donetsk, Poltava and Zaporizhia regions. However, the geography of the place of registration of these holdings or their parent companies includes Cyprus, the United Kingdom, the Netherlands and Switzerland. The group of companies Metinvest occupies an informal monopoly position in the market of ore mining and steel production in Ukraine. Thus, the main items of Ukraine's exports are under control or are significantly influenced by a small number of vertically integrated holdings, which may indicate a low level of competition. In these circumstances, one of the most important functions of the state in this area is to maintain a competitive environment and limit monopolies. At the same time, the lack of quality legislation does not allow the state to fully regulate and influence the real situation in the country.

Keywords: agricultural products, export, monopolization, iron industry

\section{Аналіз рівня монополізації сировинного експорту України}

\section{П.О. Макаренко}

Інститут географії НАН Украӥни, Київ, Україна, m_peter@ukr.net

Анотація. Формуванню конкурентоспроможної національної економіки України перешкоджає слабка система контролю монополізації. Діяльність олігархічних кланів стимулювала політичне лобіювання, протизаконний вплив на керівництво незалежних підприємств, їх рейдерське захоплення, що призвело до уповільнення технічного прогресу України, зростання рівня тіньової економіки та зниження ï ефективності. Існуюча тенденція до збільшення експорту сировини та монополізація основних галузей експорту ставить економіку України ще в більшу залежність від діяльності кількох монополістів. Метою даної роботи був аналіз рівня монополізації основних галузей експорту України - продукції сільського господарства та чорної металургії. 3'ясовано, що аграрному сектору економіки України властива дуальна структура - корпоративні (агрохолдинги) та індивідуальні господарства (сімейні ферми та господарства населення), яким властиві різноспрямовані напрямки розвитку. Аналіз регіональної присутності агрохолдингів показав, що найбільші компанії-землевласники оброблюють земельні ділянки майже в усіх областях України. Показано, що на даний момент в агропромисловому секторі України склалася ситуація, за якої корпоративні землевласники контролюють 18,4\% оброблюваних земель, існують у вигляді вертикально інтегрованих холдингів, які спеціалізуються на вирощуванні експортно-орієнтованих культур. Показано, що специфіка розташування корисних копалин пояснює географічне розташування підприємств чорної металургії в Дніпропетровській, Донецькій, Полтавській та Запорізькій областях. Проте, географія місця реєстрації цих холдингів або їх материнських компаній, які ведуть основну діяльність в Україні, включає в себе Кіпр, Великобританію, Нідерланди та Швейцарію. Неформальне монопольне 
становище на ринку видобутку руди та виробництва сталі в Україні займає група компаній «Метінвест». Таким чином, головні статті експорту України є підконтрольними або підпадають під значний вплив невеликої кількості вертикально інтегрованих холдингів, що може свідчити про низький рівень конкуренції. В даних умовах однією 3 найголовніших функцій держави в даній сфері є підтримка конкурентного середовища та обмеження монополізму. Водночас, відсутність якісного законодавства не дозволяє державі повною мірою регулювати та впливати на реальну ситуацію в країні.

Ключові слова: продукція сільського господарства, експорт, монополізація, чорна металургія

\section{Introduction}

Ensuring the competitiveness of the domestic economy is one of the most pressing issues over the past 30 years. Ukraine remains an outsider in the global competitiveness ranking, lagging far behind in many macroeconomic parameters and in the business environment, market monopolization, institutional and legislative level not only from developed countries but also from countries with transformational economies (Fyliuk, 2015).

The process of monopolization of the economy is controversial. On the one hand, monopolies have more opportunities to develop production, finance research, create and implement innovations. Monopolies are more large enterprises, which are characterized by the highest efficiency and lowest production costs. However, monopolies set monopolistically high prices and in a situation of weakening or lack of competition inhibit scientific and technological progress (Kovalchuk, 2013). State-created monopolies governed by administrative means and monopolies created by oligarchic financial-industrial groups based on the principle of monopoly niches are a real threat to Ukraine's competitiveness. The biggest negative consequences of this situation are the rapid decline in competitive advantage for most industries in the country (Chernelevs'ka, 2014).

The formation of a competitive national economy of Ukraine is also hindered by a weak system of monopoly control. According to the Antimonopoly Committee of Ukraine, the markets of crop and livestock products, certain branches of light industry, construction services, most of financial activity services are characterized as markets with a competitive structure, and markets for mobile services, coke, gasoline, beer have an oligopolistic structure (Krykunova, 2014). The restraint of demonopolization of certain markets in the domestic economy is explained by the use of administrative resources, which significantly complicates the development of competition. Thus, during the years of independence, the Cabinet of Ministers of Ukraine consolidated state assets and created state joint-stock companies in the mining and mining industries, medical and microbiological industry, oil and gas industry, elevator, flour and cereals and fodder industry, as well as 24 companies in the engineering industry (Chernelevs`ka, 2014).

At the same time, there is a growing influence of informal monopolies operating through non-market instruments through the pooling of power and capital (Lahutin, 2012). A significant part of monopolized commodity markets in Ukraine is formed due to natural monopolies in such industries as electricity, communications, transport and utilities (Kovalchuk, 2013). At the same time, the activities of oligarchic clans stimulated political lobbying, illegal influence on the management of independent enterprises, their raider seizure, which led to a slowdown in Ukraine's technical progress, increasing the shadow economy and reducing its efficiency (Taranych, 2019). The country failed to realize an investment and innovation breakthrough, to reform the structure of the economy in the direction of knowledge-intensive industries, which was a consequence of the monopolization of strategically important markets for economic growth and economic security (Fyliuk, 2015).

Since the 1990s, Ukraine's foreign trade has been characterized by excessive dependence on raw material exports. During the period of 2015-2019, the basis of exports was represented by agricultural products (primarily crop production) and ferrous metallurgy, which averaged $57.78 \%$ of the total exports of goods (Ukrstat). Given the specifics of these industries, they are characterized by the creation of vertically integrated associations of enterprises, which encourages the consolidation of such associations in one hand. Thus, the current trend towards increasing exports of raw materials and the monopolization of major export industries puts Ukraine's economy even more dependent on the activities of several monopolists.

The purpose of this work was to analyze the level of monopolization of the main exports of Ukraine agricultural products and ferrous metallurgy.

\section{Materials of the article and methods of research}

Analytical and analytical-statistical research methods are used in the work, in particular, analysis of literature of domestic authors, systematization and generalization of data of the State Statistics Service of Ukraine, the Antimonopoly Committee of Ukraine and other open sources. 


\section{Results and their analysis}

Attracting investment, as one of the main tasks of reforming the agricultural sector, in the conditions of Ukrainian agriculture was realized by the expansion of large capital, and the existing corruption component created a specific model of agriculture. In this structure, it is possible to distinguish two types of producers: corporate (agricultural holdings, vertically integrated structures, business associations, etc.) and individual (farmers and households) (Borodina \& Prokopa, 2012).

Since the 2000s, the formation of corporate capitalism and the capitalization of agricultural production has begun in the agricultural sector of Ukraine's economy. This was based on the concentration of agricultural land and the attraction of industrial capital, which became possible as a result of legislative changes in the formation of holding structures, including in the field of production and processing of agricultural products. Holding companies were formed by the acquisition of one business entity by another in the privatization process. At the same time, some enterprises (metallurgical, coal mining, financial industries, etc.) were included in the agro-industrial sector, receiving part of the illiquid property as payment of debt (Ghutorov, 2012).

A comparative analysis of statistical data on sowing results provided by producers of three categories - OSG (personal farms), farmers and holdings - showed that as of June 1, 2019, the total
Farms in the amount of 38.268 thousand (which was less by 1.133 thousand compared to 2018) managed 15.9 million hectares, which was $81.6 \%$ of the total crop area. At the same time, holdings increased the arable land to 3.6 million hectares, which was $18.4 \%$, respectively (AgroPolit.com, 2019).

At the same time, the existing dual structure of the agricultural sector is characterized by different directions of development of its individual parts corporate and individual farms (family farms and households) have occupied their niches (Borodina \& Prokopa, 2012).

Individual farms work in a low-cost and laborintensive niche - growing potatoes, vegetables, fruits, dairy farming, etc. - and are aimed at meeting the needs of the population and filling the domestic food market. However, it was individual farms that provided production of up to $60 \%$ of gross agricultural output throughout the transformation period of the Ukrainian economy. The corporate sector monopolizes resource markets, especially financial ones, sales channels, and produces export-oriented, commercially attractive products. In addition, it has an influence on the formation of state agricultural policy and has access to state support (Borodina \& Prokopa, 2012).

This is partially confirmed by statistical data on the dependence of production volumes and the size of the enterprise in the cultivation of major export crops of Ukraine in 2019 (Fig. 1). Thus, enterprises with a sown area of 2.000 hectares produce $41.5 \%$ and $36.1 \%$ of the total production of cereals, legumes and corn,

Table 1. Comparative characteristics of the area of sowing crops by different types of agricultural producers (AgroPolit.com, 2019)

\begin{tabular}{|l|l|l|l|l|}
\hline & The size of the crop area, ha & Quantity, pcs & Crop area, ha & \% of the total area of crops \\
\hline \multirow{2}{*}{} & Дo 500 & 31097 & 3047501 & 15.7 \\
\cline { 2 - 6 } & $500-1000$ & 2688 & 1930809 & 9.9 \\
\cline { 2 - 6 } & $1000-5000$ & 4130 & 8546973 & 43.9 \\
\cline { 2 - 6 } & $5000-10000$ & 353 & 2351952 & 12.1 \\
\hline \multirow{2}{*}{ 点 } & $10000-20000$ & 92 & 1213451 & 6.2 \\
\cline { 2 - 6 } & $20000-50000$ & 59 & 1748738 & 9.0 \\
\cline { 2 - 6 } & $<$ more than 50000 & 9 & 609267 & 3.1 \\
\hline
\end{tabular}

number of companies that reported sowing was 38.451 thousand (table 1). OSG sowed 8.393 million hectares, and legal entities - 19.449 million hectares. respectively. In the case of wheat cultivation, this figure is $18.3 \%$. Enterprises with sown areas from 200 ha to 2000 ha grew a total of $66.1 \%$ of wheat (Ukrstat). 


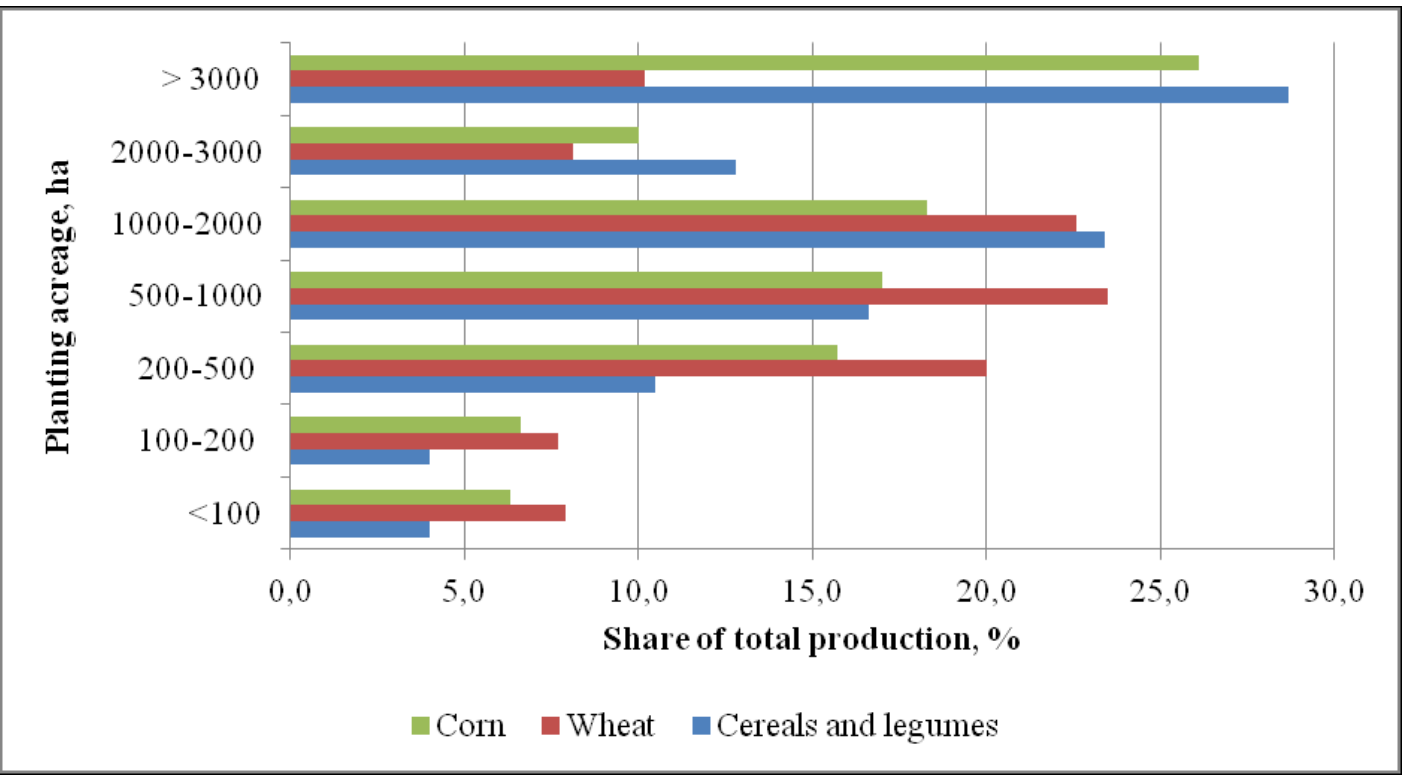

Fig.1. Dependence of production volumes and size of the enterprise when growing major export crops in 2019 (Ukrstat)

In addition, the capabilities of corporate agroindustrial enterprises allow for significant research and implementation of innovative approaches and technologies. Despite the fact that one of the typical features of small sized foreign farms, especially family type, is a higher yield per hectare, in Ukraine the situation is reversed (Fig. 2). According to Ukrstat, in 2019 the yield per 1 hectare grew with the increase in the size of the enterprise. This is less observed in
Analysis of the largest agro-industrial holdings as of 2020 is shown in the table.2. The first ten largest agricultural holdings in Ukraine have a total land bank of 2.660 million hectares, while the first three have 1.400 million hectares (latifundist.com).

The analysis of the regional presence of agricultural holdings showed that the largest landowners cultivate land plots in almost all regions of Ukraine. Some holdings with a land bank of less than

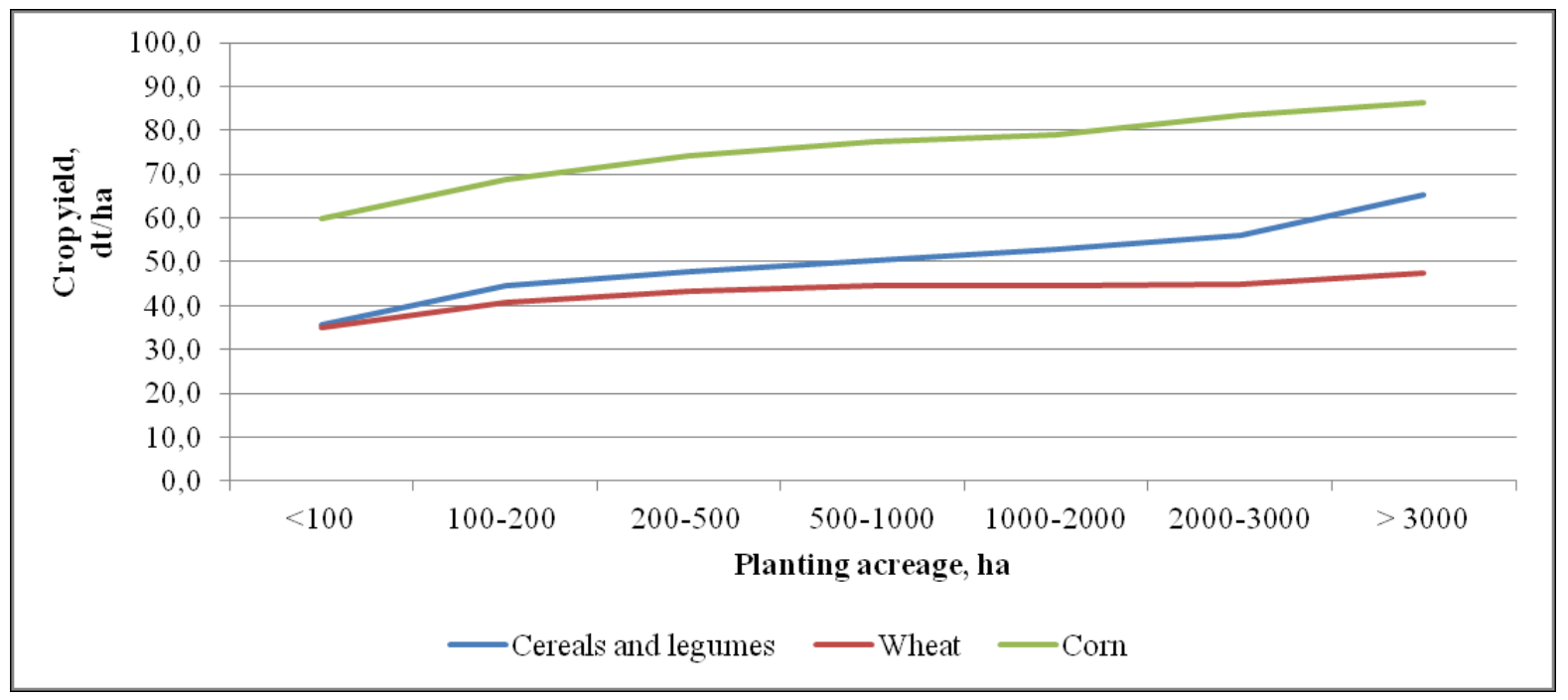

Fig.2. Yield of the main export crops depending on the area of crops of the enterprise in 2019 (Ukrstat)

the example of wheat cultivation, but the yield of corn and grain crops at enterprises larger than 3000 ha is higher by $30.5 \%$ and $45.3 \%$ (Ukrstat). Agricultural holdings tend to monocultural production, and their focus on foreign markets leads to the displacement of labor-intensive crop and livestock products, imbalance of local agricultural complexes and food markets (Kyrylov, 2014; Gheec, 2010).
200.000 hectares have a certain regional consolidation. For example, Continental Farmers Group's activities are limited to the western region, HarvEast plots are concentrated in Donetsk and two northern regions, Industrial Dairy Company is present in the northeastern region, and Ukrprominvest cultivates land in the central and south-western regions of Ukraine.

Having analyzed the above, at present in the 
Table 2. The largest agro-industrial holdings of Ukraine by land bank, 2020 (latifundist.com)

\begin{tabular}{|c|c|c|c|}
\hline Name of the holding & $\begin{array}{l}\text { Land area, } \\
\text { thousand ha }\end{array}$ & Regional location & Owner \\
\hline Kernel & 530 & $\begin{array}{l}\text { Ternopil, Odessa, Mykolaiiv, Kirovohrad, Cherkasy, } \\
\text { Poltava, Sumy, Chernihiv, Kharkiv, Dnipro, Khmel- } \\
\text { nytsky regions }\end{array}$ & Andriy Verevsky \\
\hline Ukrlandfarming & 500 & 22 regions of Ukraine & Oleg Bakhmatyuk \\
\hline Myronivsky HP & 370 & $\begin{array}{l}\text { Kyiv, Cherkasy, Poltava, Sumy, Dnipro, Donetsk, } \\
\text { Kherson, Vinnytsia, Ivano-Frankivsk regions }\end{array}$ & Yuri Kosyuk \\
\hline Agroprosperis & 300 & $\begin{array}{l}\text { Sumy, Chernihiv, Kharkiv, Poltava, Vinnytsia, } \\
\text { Zhytomyr, Khmelnytsky, Ternopil, Rivne, Volyn and } \\
\text { Lviv regions }\end{array}$ & $\begin{array}{l}\text { "NCH Capital" (George Rohr } \\
\text { and Maurice Tabasinique) }\end{array}$ \\
\hline Astarta-Kyiv & 235 & $\begin{array}{l}\text { Poltava, Vinnytsia, Ternopil, Khmelnytsky, Kharkiv, } \\
\text { Cherkasy, Chernihiv and Zhytomyr regions }\end{array}$ & Victor Ivanchyk \\
\hline $\begin{array}{l}\text { Continental Farmers } \\
\text { Group }\end{array}$ & 195 & $\begin{array}{l}\text { Ternopil, Khmelnytsky, Ivano-Frankivsk, Cher- } \\
\text { nivtsi, Lviv regions }\end{array}$ & SALIC Ltd. (Saudi Arabia) \\
\hline Epicenter K & 160 & $\begin{array}{l}\text { Cherkasy, Khmelnytsky, Kyiv, Ternopil and Vin- } \\
\text { nytsia regions }\end{array}$ & $\begin{array}{l}\text { Galyna Gerega and Oleksandr } \\
\text { Gerega }\end{array}$ \\
\hline HarvEast & 127 & Donetsk, Kyiv and Zhytomyr regions & $\begin{array}{l}\text { "System Capital Manage- } \\
\text { ment" (Rinat Akhmetov) and } \\
\text { "Smart Holding" (Vadim } \\
\text { Novinsky) }\end{array}$ \\
\hline Industrial dairy company & 123 & Poltava, Chernihiv, Sumy regions & Oleksandr Petrov \\
\hline Ukrprominvest-Agro & 120 & $\begin{array}{l}\text { Vinnytsia, Zhytomyr, Cherkasy, Poltava, Dniprop- } \\
\text { etrovsk and Kirovohrad regions }\end{array}$ & $\begin{array}{l}\text { "Ukrprominvest" (Petro Poro- } \\
\text { shenko) }\end{array}$ \\
\hline
\end{tabular}

agro-industrial sector of Ukraine there is a situation in which corporate landowners control $18.4 \%$ of arable land. However, these companies exist in the form of vertically integrated holdings that specialize in growing export-oriented crops. In connection with the adoption of the Law on the Land Market No 217810 , the existing agricultural holdings will have the opportunity to further increase the land bank.

The second largest goods export group after agricultural products are metallurgical industry products. The structure of exports of metallurgical products is characterized by a significant share of semi-finished products, i.e. products with low added value. Thus, semi-finished products accounted for $43 \%$ of total exports of hardware in 2018 (Hrynko \& Androsova, 2019). In general, the structure of production of the main categories of products of the metallurgical complex for 2019 is shown in the Fig.3. Compared to 2018, the production of cast iron decreased by $2.4 \%$, steel - by $1.2 \%$, and rolled metal - by $0.9 \%$ (Ukrmetalurgprom, 2020).

In contrast to the agricultural sector, the specifics of this industry determines the presence of large enterprises in the first place. The modern metallurgical industry of Ukraine is represented by large diversified groups of companies in the form of vertically integrated, horizontally integrated and conglomerate business groups (Kasianchuk, 2016). This can be explained by the fact that the creation of vertically integrated companies based on mining, coke and metal, allows to reduce VAT by almost two times, which is reflected in a 20 percent reduction in unit cost. That is, the vertical integration of metallurgical industry structures reduces tax, management and technical costs (Plavshuda, 2013).

At the same time, privatization processes that accompany the creation of holding structures primarily satisfy the private interests of the owners of these enterprises and deprive the state of the opportunity to influence this area (Plavshuda, 2013). Thus, the constant influence of lobbyists on the Verkhovna Rada and the Cabinet of Ministers of Ukraine facilitated the adoption of laws, regulations and other regulations, which allowed some enterprises of the mining and metallurgical sector to receive installments of some payments to the budget at various levels, reduced tax deductions, etc. Mazur \& Skoroxod, 2009). At the same time, the funds saved were not used for the development and construction of production capacity, especially during periods of extremely high prices for raw materials and ferrous metallurgy products and, consequently, surplus profits (for example, in 2010 the annual profit from iron ore exports alone was about 4 billion USD.) (Mazur, 2016). As a result, insufficient modernization and loss of industrial capacity in Donbass (approximately 3.3 million tons of steel per year) (Hrynko \& Androsova, 2019) led to a decrease in steel production by 53.04 between 2008 


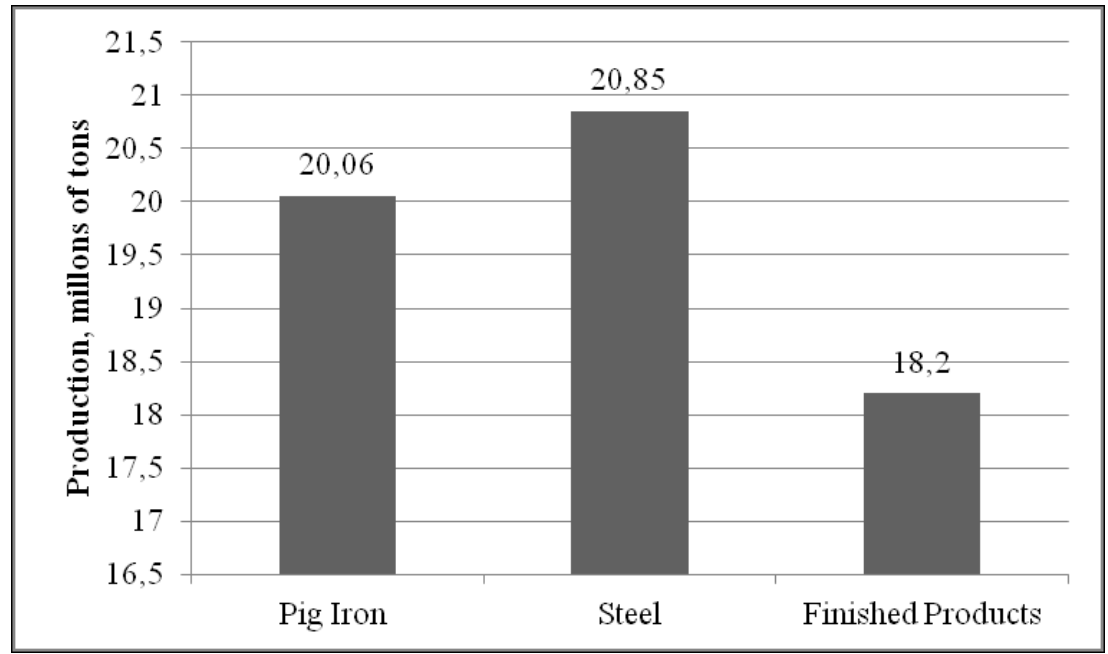

Fig. 3. Production of the main categories of products of the metallurgical complex for 2019 (Ukrmetalurgprom, 2020).

and 2018. \%, from 42.8 million tons to 20.1 million tons annually (World Steel Association).

As of 2018, in the market of ferrous metallurgy of Ukraine the dominant position is occupied by several largest holdings (Table 3). The specific location of minerals explains the geographical location of ferrous metallurgy enterprises. The main areas for their concentration are Dnipropetrovsk, Donetsk, Poltava and Zaporizhia regions. However, the geography of the place of registration of these low rents for iron ore mining and are subsidized by Ukrzaliznytsia (Gholovnjov \& Vinnichuk, 2019). However, this holding reflected the crisis situation in the metallurgical industry that has developed in the Ukrainian market in recent years - in 2017, Metinvest for the first time in its history showed losses, while only profit was recorded before (Hrynko \& Androsova, 2019).

Most The majority of other companies in the industry are integrated into the holding structures

Table 3. The largest enterprises in ferrous metallurgy of Ukraine (Gholovnjov \& Vinnichuk, 2019)

\begin{tabular}{|l|l|l|l|}
\hline Name of Company & $\begin{array}{l}\text { Total income, billion } \\
\text { UAH, 2018 }\end{array}$ & Regional location & Owner \\
\hline Metinvest & 323 & $\begin{array}{l}\text { Dnipro, Donetsk, } \\
\text { Luhansk, Zaporizhia } \\
\text { regions }\end{array}$ & $\begin{array}{l}\text { "System Capital Management" (Cyprus, } \\
\text { Rinat Akhmetov) and "Smart Holding” } \\
\text { (Netherlands, Vadim Novinsky) }\end{array}$ \\
\hline ArcerolMital Kryvyi Rih & 68 & Dnipro region & ArcerolMittal, Luxembourg \\
\hline Ferrexpo & 35 & Poltava region & $\begin{array}{l}\text { Kostiantyn Zhevago, registered in Swit- } \\
\text { zerland }\end{array}$ \\
\hline Interpipe & 29.2 & Dnipro region & $\begin{array}{l}\text { "EastOne", (Great Britain, Victor Pin- } \\
\text { chuk) }\end{array}$ \\
\hline
\end{tabular}

holdings or their parent companies, which have their core business in Ukraine, includes Cyprus, the United Kingdom, the Netherlands and Switzerland. Thus, most metallurgical enterprises in Ukraine are owned or controlled by large financial and industrial groups (Hrynko \& Androsova, 2019).

The Groups of companies Metinvest holds an informal monopoly position in the market of ore mining and steel production in Ukraine and in 2018 was the largest company in Ukraine; however, some sources claim that the privatization of the holding's assets took place without competition and at a reduced cost, and the group's companies pay extremely of individual businessmen (Konstantin Zhevago, Viktor Pinchuk) and the international corporation ArcerolMital. Thus, one of the main items of raw material exports of Ukraine is fully controlled by individual holdings owned by oligarchs and foreign companies.

Some studies argue that to address the situation in the metallurgical industry, first of all, it is necessary to create a state regulatory organization, the purpose of which should be to develop regulations for metallurgical enterprises, cooperation with investors to attract innovation, ensure the introduction of new energy-saving technologies and environmental 
protection technologies, purchase of new equipment that will stimulate the production of high quality products and will change the existing paradigm of dependence on exports of raw materials and low competitiveness in international markets (Hrynko \& Androsova, 2019).

The experience of the world leader in metallurgy - China can also help Ukraine in this situation. Establishing a full production cycle in the country, deepening research, improving the technical and engineering base, expanding intersectoral cooperation, especially with the chemical industry will improve the properties of steel and cast iron (Hrynko, 2013).

\section{Conclusions}

The monopoly of certain sectors of the economy destroys competition as the basis of market selfregulation. In the Ukrainian economy, the main export items - products of agriculture, mining and metallurgical complexes - are controlled or subject to significant influence of a small number of vertically integrated holdings, which may indicate a low level of competition. In these circumstances, one of the most important functions of the state in this area is to maintain a competitive environment and limit monopolies. At the same time, the lack of quality legislation does not allow the state to fully regulate and influence the real situation in the country.

\section{References}

Borodina, O., Prokopa I. (2012). Jaka modelj aghrosektoru neobkhidna Ukrajini [What model of agricultural sector does Ukraine need?]. Dzerkalo tyzhnja. Ukrajina, (18) (in Ukrainian).

Chernelevs 'ka O. L. (2014). Monopolizaciya ekonomiky' Ukrayiny' yak osnovna zagroza dlya yiyi konkurentozdatnosti [Monopolization of Ukraine's economy as the main threat to its competitiveness]. Investy 'ciyi: prakty'ka ta dosvid, (13), 22-24 (in Ukrainian)..

Derzhavna sluzhba statystyky Ukrainy [State Statistics Service of Ukraine]. Retrieved from: http://www. ukrstat.gov.ua/ (in Ukrainian).

Fyliuk H.M. (2015). Vysokyi riven monopolizatsii ukrainskoi ekonomiky - barier na shliakhu pidvyshchennia rivnia yii konkurentospromozhnosti [The high level of monopolization of the Ukrainian economy is a barrier to increasing its level of competitiveness]. Visnyk Kamianets-Podilskoho natsionalnoho universytetu imeni Ivana Ohiienka. Ekonomichni nauky, (10), 102-109 (in Ukrainian).

Hrynko T. V. (2013). Transkordonne spivrobitnytstvo i stratehii rozvytku metalurhiinykh pidpryiemstv [Cross-border cooperation and strategies development of metallurgical enterprises]. Visnyk Skhidnoukrainskoho natsionalnoho universytetu imeni Volodymyra Dalia, 17 (206), 158-161(in Ukrainian).

Hrynko, T. V., Androsova I. O. (2019). Problemy ta perspektyvy rozvytku metalurhiinoi haluzi $\mathrm{V}$ Ukraini [Problems and prospects of development of the metallurgical industry in Ukraine]. Problemy ekonomyky, (2 (40)). (in Ukrainian).

Gheec V.M. (2010). Novyj kurs: reformy v Ukrajini 2010-2015: nacionaljna dopovidj [New course: reforms in Ukraine 2010-2015: national report]. Nacionaljna biblioteka imeni VI Vernadsjkogho NAN Ukrajiny (in Ukrainian).

Gholovnjov, S., Vinnichuk Ju. (2019). 200 najbiljshykh kompanij Ukrajiny 2018 roku [200 largest companies of Ukraine in 2018]. Retrieved from: https://biz.censor.net.ua/resonance/3147570/200_ nayiblshih_kompanyi_ukrani_2018_roku (in Ukrainian).

Ghutorov A.O. (2012). Korporatyzacija siljsjkogho ghospodarstva V Ukrajini [Corporatization of agriculture in Ukraine]. Ekonomika i proghnozuvannja, (4), 82-92 (in Ukrainian).

Kasianchuk T. (2016). Dyversyfikatsiia diialnosti providnykh hrup kompanii metalurhiinoi haluzi ta otsinka yii rivnia [Diversification of leading groups of companies in the metallurgical industry and assessment of its level]. Naukovyi visnyk Odeskoho natsionalnoho ekonomichnoho universytetu, (1), 56-70 (in Ukrainian).

Kovalchuk N.V. (2013). Vplyv monopolii na suspilstvo ta ekonomiku Ukrainy [The impact of monopolies on the society and economy of Ukraine.]. Visnyk Dnipropetrovskoi derzhavnoi finansovoi akademii. Ekonomichni nauky, 1 (in Ukrainian).

Krykunova, V.M. (2014). Analiz stanu konkurentnoho seredovyshcha $\mathrm{v}$ Ukraini [Analysis of the state of the competitive environment in Ukraine.]. Biznes-navihator, (1), 58 (in Ukrainian).

Kyrylov Ju. Je. (2014). Rolj ta misce aghrokholdynghiv $\mathrm{v}$ podaljshomu rozvytku aghrarnogho sektoru ekonomiky Ukrajiny [The role and place of agricultural holdings in the further development of the agricultural sector of the Ukrainian economy]. Tavrijsjkyj naukovyj visnyk: naukovyj zhurnal. Kherson: Ghrynj DS, 222-233 (in Ukrainian).

Lahutin V.D. (2012). Suchasna metodolohiia doslidzhennia rynkovo-konkurentnykh vidnosyn [Modern methodology of research of market-competitive relations.]. Materials of the International scientific-practical conference: «The content and main directions of paradigmatic shifts in the structure of economic theory of the XXI century», 60-62 (in Ukrainian).

Mazur V. L. (2016). Problemy promyslovoi polityky v Ukraini [Problems of industrial policy in Ukraine]. 
Ekonomika Ukrainy, (11), 3-18 (in Ukrainian).

Mazur, V., Skoroxod O. (2009). Konkurentni pozy'ciyi pidpry'yemstv girny'cho-metalurgijnogo kompleksu Ukrayiny' [Competitive positions of the enterprises of the mining and metallurgical complex of Ukraine]. Ekonomika Ukrayiny', (3), 4-18 (in Ukrainian).

Plavshuda K.V. (2013). Formuvannja vertykaljno integhrovanykh kholdynghovykh struktur $\mathrm{u}$ metalurghijnij promyslovosti Ukrajiny [Formation of vertically integrated holding structures in the metallurgical industry of Ukraine]. Juryst Ukrajiny, (2), 96-101 (in Ukrainian).

Taranych O. (2019). Korporatyvnyj sektor-dzherelo ekonomichnogho zrostannja Ukrajiny [Corporate sector is a source of economic growth in Ukraine.]. Ghalycjkyj ekonomichnyj visnyk Ternopiljsjkogho nacionaljnogho tekhnichnogho universytetu, 58(3), 31-36 (in Ukrainian). doi. org/10.33108/galicianvisnyk_tntu2019.03.031

Top 100 latifundists of Ukraine (2020). URL: https:// latifundist.com/rating/top100\# (in Russian).

World Steel Association. Retrieved from: http://www. worldsteel.org/

Ukrmetalurgprom. The Results of the Mining \& Metallurgical Complex of Ukraine Activity in 2019. Retrieved from: http://www.ukrmetprom. org/pidsumki-roboti-gmk-ukraini-u-2019-r/

Zemeljnyj bank Ukrajiny 2017-2019 roky: skiljky zemli obrobljajutj kholdynghy, fermery ta OSGH [Land Bank of Ukraine 2017-2019: how much land is cultivated by holdings, farmers and individual rural households]. Retrieved from: https://agropolit. com/spetsproekty/636-zemelniy-bank-ukrayini2017-2019-roki-skilki-zemli-obroblyayutholdingi-fermeri-ta-osg (in Ukrainian). 